\title{
A RESTAURANT QUALITY MODEL BASED ON MARKETING FACTORS
}

\author{
Marko Kukanja, Doris Gomezelj Omerzel, Boris Bukovec
}

\section{Introduction}

In the highly competitive restaurant industry, satisfying guests should be the critical objective of all businesses that wish to prosper and encourage repeat purchases. However, ensuring proper quality in restaurants is limited by a number of industry-specific factors, including volatile demand, small businesses, intense competition, the wide range of food and beverage products offered, the inseparability of production and consumption, intangibility of services, labour-intensive production, the importance of employees' attitude towards guests and many other factors that significantly affect the level of overall service quality. A crucial challenge to all restaurateurs today is how to provide a quality offering that is not only compelling for guests but also superior to that of business competitors. In order to gain an advantageous edge in this highly competitive environment, the marketing literature has consistently emphasized the importance of marketing orientation as a strategic tool. The growing recognition of the customerbased marketing approach (i.e., business to consumer) has suggested that implementing quality as a marketing tool is the essential element in fostering customer relationships and sustainable market share (Wang, Law, Hung, \& Guillet, 2014). Understanding customers' needs is the first step in delivering quality services. The best way to manage customers' expectations is to find out what their needs and wants are, strategize how to meet them and implement these strategies in practice. In the scientific literature, there are several theoretical models to explore customers' expectations and assess service quality. After the introduction of the generic SERVQUAL instrument in 1988 by Parasuraman, Zeithaml and Berry, the issue of restaurant service quality has received considerable critical attention. Several attempts have been made (Kim, Ng, \& Kim, 2009; Sulek \& Hensley, 2004; Vanniarajan, 2009) to improve and develop specific quality measurement techniques suited to the needs of the restaurant industry (e.g., DINESERV, SERVPERF, CIERM, TANGSERV). All of these techniques focus on specific aspects of service delivery (techniques are presented in chapter 1.3). As food is the fundamental component of the dining experience, it undoubtedly has a significant impact on guests' satisfaction (Vanniarajan, 2009). Despite the importance of food quality, some scholars have focused on the service encounter aspect of service quality (Ayeh \& Chen, 2013; Edvardsson, 2005; Han, Back, \& Barrett, 2010). Further examination reveals that most studies (Andaleeb \& Conway, 2006; Barber, Goodman, \& Goh, 2011; Mosavi \& Ghaedi, 2012; Raajpot, 2002; Voon, 2012) have empirically investigated the role of different and specific quality factors, such as environment, tangibles, cleanliness, price perception, and so forth. One interesting finding that emerges from the comparison of these studies is that research results are mutually inconsistent, as they emphasize the importance of different quality factors. Nonetheless, no study has determined which marketing factor (7P) is the most important in assessing the quality of the dining experience. Therefore, it would be of academic significance to summarize the results of different studies and to empirically investigate the importance of different marketing factors in assessing the quality of restaurant offerings.

To fill this research gap, the current study focuses on seven marketing factors (marketing mix) that, according to Kotler (2004), form the fundamental part of restaurant offerings. We assume that all marketing factors have a significant impact on guests' satisfaction as they form an inseparable part of the dining experience. The purpose of this article is to 
describe the development of a marketingoriented model for measuring restaurant quality and to discuss its properties and potential applications. More specifically, research construct clarification is mainly related to our main research question: How do different marketing quality factors influence the assessment of overall restaurant quality (7P) from the guests' perspective? We therefore hypothesize:

$\mathrm{H} 1$ : All seven marketing quality dimensions (7P) have a statistically significant influence on guests' quality perception.

Based on Kotler's marketing mix strategic approach, Edwards (2013) and Sedmak (2011) highlighted the importance of the overall quality experience. According to these authors, all quality factors have to be considered together when evaluating the restaurant experience, as they all influence guests' quality expectations and perceptions. The restaurant offering must therefore be consistent, coherent and designed in accordance with guests' expectations (Sedmak, 2011). We hypothesize that:

$\mathrm{H} 2$ : Guests perceive the quality of delivered restaurant offerings as coherent.

Testing these hypotheses calls for a literature review inquiry into recent research on restaurant quality. Based on a thorough literature review, a quality model was developed based on marketing factors for measuring customers' perceptions of restaurant quality. In the second part of the study, the model was empirically tested. The overall structure of the study consists of four chapters, including this introductory chapter. Chapter one begins by laying out the theoretical dimensions. Chapter two is concerned with methodology - it describes the generation of model items and provides an evaluation of the model's reliability and factor structure. Finally, the conclusion presented in the last chapter gives a brief summary and critique of the findings.

\section{Theoretical Background \\ 1.1 Service Quality}

Defining service quality requires a specific approach to quality measurement, as it is not based on general objectivity and measurability. The approach from the standpoint of the customer is based on a highly subjective perspective. While a variety of definitions have been suggested (Grönroos, 1984, 1990; Langer, 1997; Parasuraman et al., 1988; Reeves \& Bednar, 1995), this paper is based on the definition suggested by Parasuraman, Zeithaml, and Berry (1985), who defined service quality as the ability of a service to fulfil and exceed guests' expectations. The common characteristic of all service quality definitions (Parasuraman et al., 1988; Reeves \& Bednar, 1995; Ryu \& Jang, 2007; Van Vaerenbergh, Larivière, \& Vermeir, 2012) is the consumerbased concept, which makes service quality a highly subjective and relative phenomenon that differs based on who is judging the service. In our study, specific marketing factors involved in the marketing mix (7P) are used as key quality dimensions.

\subsection{Theoretical Models of Service Quality}

A large and growing body of scientific literature has investigated the theoretical concept of service quality. Several attempts have been made to capture the essential characteristics of service quality in theoretical models. These models are especially important because they provide a theoretical basis for various techniques (instruments) for measuring service quality. The American school (Parasuraman, Berry, \& Zeithaml, 1993; Parasuraman, Zeithaml, \& Berry, 1994) is mainly focused on identifying the criteria that consumers use in evaluating the quality of services. Researchers have contributed a five-step model of service quality and an instrument for measuring service quality - the SERVQUAL instrument - in which they defined five dimensions of service quality: Reliability, Assurance, Tangibles, Empathy, and Responsiveness. Meanwhile, researchers from the Scandinavian school (Grönroos, 1990; Lehtinen \& Lehtinen, 1991) have identified two major aspects of service quality: technical quality (the tangible aspect of the quality) and functional quality. Drawing on an extensive range of sources, the scholars (Candido \& Morris, 2000; Lin, Chan, \& Tsai, 2009) used various methods in an attempt to create valid and overall-service quality models. Candido and Morris (2000) defined a new model with 14 steps, but an in-depth analysis revealed that the model is mainly based on the five-step model. Overall, none of these modified models 
received a significant scientific validation. Conversely, several authors highlighted the need to break the link between the traditional American and Scandinavian schools and proposed alternative quality models. Lin et al. (2009) upgraded the traditional IPA (Importance Performance Analysis) model and developed a new model called IPGA. The IPGA model is designed to optimize the use of production resources with the aim of improving the quality of services offered. Nevertheless, all these studies highlight the need for future development of service quality management.

\subsection{Tools for Measuring Service Quality}

In our study, we focus on tools (techniques) that collect quality information based on pre-determined standards, although the customers' feedback can also be obtained by a number of qualitative techniques. Despite the unquestionable significance of qualitative techniques, we decided to use quantitative techniques. Some of these techniques (often also referred to as models) measure service quality basing on the quality gaps that occur as a result of differences between guests' expectations and perceptions (SERVQUAL, DINESERV); some are one-dimensional and focus solely on service performance evaluation (SERVPERF, Dineserv.per); some combine quality and importance measurement of different service factors (SERVIMPERF); some focus on employees' responses to specific critical situations (Critical Incident Technique - the extended model); and, finally, some address external evaluators (AAA Diamond, Michelin Stars). The predominant quantitative measurement technique is the SERVQUAL instrument (Marković, Raspor, \& Šegarić, 2012), which measures quality basing on the gap between guests' expectations and perceptions. According to Aigbedo and Parameswaran (2004), all five dimensions of the SERVQUAL instrument have not yet been fully validated. Therefore, the authors propose additional metrics that would better explain the gap between expectations and perceptions. Other authors (Dedeke, 2003; Jensen \& Hansen, 2007; Juwaheer, 2004; Ryu, 2005) have highlighted the need for a tailored approach to service quality measurement. Despite these criticisms, however, SERVQUAL remains one of the most commonly used service quality measurement techniques (Marković et al., 2012). Inclusion of quality dimensions in different restaurant service quality models is presented in Table 1.

As can be seen from the table above, specific techniques, such as Tangserv and CIERM, have moved away from the traditional RATER dimensions of the SERVQUAL instrument. Our findings are consistent with

\section{Tab. 1: Inclusion of quality dimensions in different service quality models}

\begin{tabular}{|c|c|c|c|c|c|c|c|c|}
\hline Dimension & 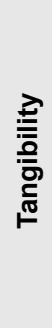 & 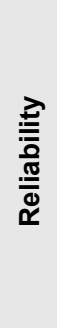 & 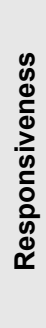 & 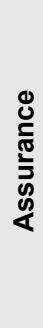 & 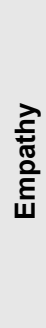 & 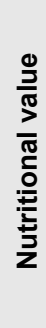 & 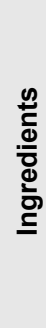 & 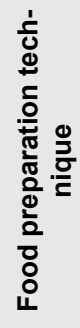 \\
\hline SERVQUAL & $x$ & $x$ & $x$ & $x$ & $x$ & & & \\
\hline DINESERV & $x$ & $x$ & $x$ & $x$ & $x$ & & & \\
\hline Dineserv.per & $x$ & $x$ & $x$ & $x$ & $x$ & & & \\
\hline Tangserv & $x$ & & & & & & & \\
\hline CIERM & & & & & & $x$ & $x$ & $x$ \\
\hline
\end{tabular}


those of other studies (Cronin \& Taylor, 1994; Llosa, Chandon, \& Orsingher, 1998; Tribe \& Snaith, 1998) in suggesting the necessity of moving away from these traditional dimensions.

\section{Methodology}

\subsection{Research Process and Sample Description}

Following the conceptualization and operationalization of the service quality construct (see Fig. 1), a 35-item instrument for assessing customer perception of restaurant quality was formulated and empirically tested. Although in many questionnaires (Marković et al., 2012) individual quality factors are substantively combined to express characteristics of several factors in a single, uniform quality factor (e.g., attractiveness of car parks and surrounding areas), in our study we have exclusively used one quality characteristic for the description of each quality factor (see Tab. 2). The level of customers' perceptions was measured on a five-point Likert scale, ranging from 1 (strongly disagree) to 5 (strongly agree). The model is based on the performance aspect of quality measurement. In doing so (focusing on performance assessment), we support the theoretical findings of several authors (Abdullah \& Rozario, 2009; Keith \& Simmers, 2011; Landrum, Prybutok, \& Zhang, 2007) whose works emphasize the importance of a onedimensional (performance-only) approach to measuring quality. The questionnaire was pretested on ten guests and five restaurant managers who were invited to participate in the formation of the research instrument. Based on their suggestions, some minor changes were made. Our study was conducted from January to June 2014. The research was performed by ten interviewers in different restaurant settings in Slovenia - according to the official (national) classification the following types of restaurants were included in the research - "restavracije" (formal - luxury restaurants); "gostilne" (a kind of national Inns), and "okrepčevalnice" (informal - fast food facilities, snack bars and similar). A total of 323 independently operated restaurants were included in the study, representing $10 \%$ of the population of Slovenia. The research was conducted by direct interviews with domestic customers after they dined in the selected restaurants. We obtained permission from the restaurant managers before interviewing guests. Interviewing often took place at the table or, in some cases, in the restaurant lobby before guests' departure, as some managers did not allow interviews in the dining room. Randomly chosen guests were kindly asked to fill in the questionnaire. Out of a total of 2003 collected questionnaires, the final analysis is based on 1998 valid questionnaires. In the first step, descriptive statistics analysis was used to analyse respondents' demographic characteristics. The majority of respondents were an average of slightly less than 40 years of age, and the sample was composed of almost equal numbers of male $(49.4 \%)$ and female guests $(50.6 \%)$. The highest number of guests had completed secondary (vocational) education $(47.2 \%)$, while $41.5 \%$ of guests had acquired a high school education, $4.9 \%$ had only finished elementary school and $6.3 \%$ of the guests had obtained a Master's degree or PhD. A total of $14 \%$ of guests were visiting the restaurant for the first time, while $86 \%$ of guests had visited the restaurant three or more times. In addition to demographic data, the purpose of the visit (as a psychographic variable) was introduced into the study. Results show that more than half $(53.9 \%)$ of guests visited the chosen facility with the aim of satisfying hunger and thirst (physiological needs). The need to eat was followed by the purpose of socializing $(27.1 \%)$, celebrations $(9.9 \%)$, business meals $(5.2 \%)$ and other purposes $(4.1 \%)$.

\subsection{Questionnaire Development Product (Food)}

Numerous studies have reported that food is the most important quality dimension that affects both the restaurant selection process and guests' satisfaction (Gupta, McLaughlin, \& Gomez, 2007; Sulek \& Hensley, 2004; Vanniarajan, 2009). All these studies outline a critical role of food quality evaluation in correlation with other quality factors. Nevertheless, in several international studies (Kim et al., 2009; Sulek \& Hensley, 2004; Vanniarajan, 2009), food was identified as the most important quality dimension. Sulek and Hensley (2004) proposed that the quality of food should be simply defined by three key characteristics: food safety, attractiveness and digestibility. Based on literature review, we used the following quality factors in our research model: offer volume (selection of dishes), size of portions, taste, appearance, and perception of food safety. 


\section{People}

A large volume of published studies (Andaleeb \& Conway, 2006; Jaafar, Lumbers, \& Eves, 2008; Mosavi \& Ghaedi, 2012; Voon, 2012) describe the role of people as the most important quality dimension in restaurant quality management. Researchers who have looked at psychological aspects of perceptions have confirmed the correlation between guests' quality evaluation process and demographic characteristics of service staff. For example, Luohe and Tsaur (2011) confirmed the link between guests' perceptions and age; Martínez-Tur, Tordera, Peiró, and Potocnik (2011) emphasized the importance of organizational climate; and Wall and Berry (2007) concluded that guests' quality perceptions heavily depend on the type of restaurant itself. The previously mentioned finding of Wall and Berry (2007) corroborates the idea of Kim and Kachersky (2006), and Meng and Elliott (2008) who suggested that guests of fine dining restaurants are more sensitive to the attitudes of service staff. In contrast, a study conducted by Waxman (2006) in Caffe shops not only stressed the importance of staff's attitude but also revealed a rich set of social quality factors associated with staff, including warmth, a sense of belonging, familiarity, respect, trust, and support. The design of our questionnaire has been based on the results of the presented studies, and some quality factors were logically introduced from the SERVQUAL instrument (employees' politeness), DINESERV (well-trained, competent and experienced staff; number of staff) and the Tangserv model (customers' interactions with other people). Specific factors that have been introduced to our model for assessing the quality of people are: hospitality of staff, competences of service staff, sufficient number of staff to ensure quality service, importance of the presence of the restaurant manager, and the distracting presence of other guests.

\section{Price}

Subjective assessment of quality is particularly problematic in terms of individual perception of price. Kim and Kachersky (2006) state that the perceived price level and its correlation to quality are exclusively a result of an individual psychological process. This view is supported by many authors (Bhattachnaya \& Friedman, 2001; Meng \& Elliott, 2008) who have argued for the importance of individualism in price perception (especially "Fair price" perception). According to these authors, a fair price has a significant impact on guests' satisfaction and their perception of quality. The restaurant industry tends to be highly price-elastic, as a small change in price is accompanied by a large change in quantity demanded (Sedmak, 2011). We have noted, that price was not identified as the most important quality dimension in any of the presented studies. Nevertheless, many studies stressed the importance of different individual price factors (e.g., an accurate bill is also a quality factor in the DINESERV model). Following the above discussion, we may suppose that price quality can be measured based on the following price factors: understandability of prices, accurate bill, value for money, price competitiveness, and expected price level vs. actual price level.

\section{Process}

The quality of this dimension is most often assessed according to different activities of service staff (Cousins, Foskett, \& Gillespie, 2002). Ha and Jang (2010) have primarily treated the quality of the service encounter as a multidimensional construct that is most often the result of guests' subjective evaluation of several quality factors, such as the process of welcoming guests, acceptance of orders, guest attendance, and so forth. Heung, Wong, and Qu (2000) reported that the speed of service is the most important factor in determining guests' perception of quality. Nam, Ekinci, and Whyatt (2011) state that it still remains unknown how many quality factors there really are. Based on the literature review, the following quality factors were included in our model: staff responsiveness to questions, staff helpfulness in serving guests' needs, staff responsiveness, and restaurant working hours.

\section{Physical Evidence}

The importance of the physical, tangible environment has been stressed by several authors (Kim \& Moon, 2009; Mattila \& Wirtz, 2001; Namasivayam \& Mattila, 2007; Ryu \& Jang, 2007; Yunkyong, 2007), as it represents an important basis for evaluating the quality of services. A number of authors (Cheng et al., 2012; Mosavi \& Ghaedi, 2012; Ryu \& Han, 2011; Wall \& Berry, 2007) have reported that physical evidences have a different impact on guests who are visiting the restaurant for the 
first time (i.e., first-time buyers) than on guests who have already visited the restaurant in the past. In particular, factors associated with cleanliness and noise significantly influence guests' perception of quality (Barber et al., 2011; Barber \& Scarcelli, 2010). According to findings presented in this section and based on several quality models (SERVQUAL, DINESERV, Tangserv, SERVPERF), we have included the following quality factors in our questionnaire: cleanliness of the premises, neat and presentable staff, comfort, design in accordance with food offering, and sense of security.

\section{Promotion}

According to Sedmak (2011), the most common forms of promotion in the restaurant industry are advertising, sales promotions, public relations, discounts and special offers, outdoor lighted signs and boards, menus and wine lists, direct sales, invitations and announcements and special events. Direct sales present the only form of marketing communication that provides instant feedback from guests. The success of direct (personal) sales heavily depends on the competence, professionalism and charisma of the service staff. Aside from the functional aspect of quality, which heavily depends on service staff sales activities (recommendations) and guests' promotional activities (i.e., word of mouth; Keller, 2007), the quality of promotional activities is also perceived through the quality of technical factors, such as menu design (Din, Zahari, Othman, \& Abas, 2012; Sharma, Wagle, Sucher, \& Bugwadia, 2011) and discounts (Taylor \& Long-Tolbert, 2002). The evidence presented in this section suggests that there are no major differences between different forms of promotional activities in ensuring offer quality and guests' (re)purchase intention. In light of the above, we have decided to include the following promotional quality factors in our questionnaire: visible marketing signs, signs of special attention and compliments (small gifts, etc.), service staff recommendations, volume of sales campaigns and special offers, and advertising activities in social media.

\section{Placement}

In the restaurant industry, unlike the hotel industry, traditional channels of distribution have remained underdeveloped. In the restaurant industry, channels of distribution are most often direct The most important channels of distribution are: location, direct distribution and indirect distribution through travel agencies and other providers that include restaurant offerings in their offerings (Sedmak, 2011). The importance of geographical location was emphasized by Bowie and Buttle (2004) and Parsa, Self, Sydnor-Busso, and Yoon (2011). We have decided to include the following quality factors in our study (the tangible factors were logically introduced from the Tangserv model): entrance accessibility, accessible parking areas, neat and clean surroundings, perception of whether the restaurant is worth the distance travelled, and indirect distribution.

Different studies emphasize the importance of different quality factors, as researchers base their studies on different (specific) quality factors. Nevertheless, no study has empirically investigated and compared all seven marketing quality dimensions (7P).

\subsection{Analysis and Findings}

The next section of the survey was concerned with the evaluation of the perceived quality of the restaurant offering. The results presented in Table 2 show that all quality factors were evaluated relatively highly (the average mean value is 3.98). Among the seven quality dimensions, the highest-rated dimension was product \& food quality (mean 4.32), with food safety its highest rated factor (mean value 4.47). The results indicate that the lowest perceptions are related to the dimension of marketing communication (mean 3.57), with the lowest scores related to the factor "the restaurant is properly advertised in the media (2.95)". The coefficients of variation show how homogeneous guests are in the evaluation of individual quality factors.

In the next section of the study, an exploratory factor analysis was performed to assess the factor structure of perceived restaurant quality. With this factor analysis, we have tried to answer our main research question and to test our first hypothesis $(\mathrm{H} 1)$, which suggests that all seven marketing quality dimensions (7P) have a statistically significant influence on guests' quality perception. Evidence of the scale's reliability, factor structure and validity on the basis of the analysed data is presented next. First, we checked whether the answers to the above 35 variables (quality factors) were normally distributed. Because we 


\begin{tabular}{|c|c|c|}
\hline Quality dimensions (7P) & Mean & $\begin{array}{l}\text { Coefficient } \\
\text { of variation }(\%)\end{array}$ \\
\hline \multicolumn{3}{|l|}{ Product (food) } \\
\hline Selection of dishes & 4.26 & 18.64 \\
\hline Extent of portions & 4.27 & 19.11 \\
\hline Taste & 4.35 & 17.70 \\
\hline Appearance & 4.28 & 18.88 \\
\hline Food safety perception & 4.47 & 16.82 \\
\hline \multicolumn{3}{|l|}{ Physical evidences } \\
\hline Cleanliness of the premises & 4.34 & 18.04 \\
\hline Neat (presentable) staff & 4.28 & 19.30 \\
\hline Comfort & 4.22 & 20.14 \\
\hline Sense of security & 4.49 & 16.35 \\
\hline Design in accordance with food offered & 4.26 & 20.16 \\
\hline \multicolumn{3}{|l|}{ People } \\
\hline Sufficient number of staff for ensuring quality service & 4.13 & 21.40 \\
\hline $\begin{array}{l}\text { Importance of the presence of restaurant manager for } \\
\text { ensuring quality offering }\end{array}$ & 3.68 & 32.80 \\
\hline Distracting presence of other guests & 2.51 & 54.26 \\
\hline Hospitable staff & 4.26 & 20.52 \\
\hline Competences of service staff & 4.13 & 21.84 \\
\hline \multicolumn{3}{|l|}{ Promotion } \\
\hline Visible marketing signs & 3.97 & 25.69 \\
\hline Signs of special attention and compliments & 3.41 & 36.86 \\
\hline Recommendations from service staff & 4.00 & 23.68 \\
\hline Volume of sales campaigns and special offers & 3.53 & 34.31 \\
\hline Advertising activities in the social media & 2.95 & 43.90 \\
\hline \multicolumn{3}{|l|}{ Price } \\
\hline Understandability of price items & 4.52 & 16.17 \\
\hline Accurate bill & 4.67 & 13.88 \\
\hline Value for money & 4.26 & 19.95 \\
\hline Price competitiveness & 4.11 & 22.21 \\
\hline Expected price level vs. actual price level & 2.12 & 57.50 \\
\hline \multicolumn{3}{|l|}{ Placement } \\
\hline Accessible entrance & 4.01 & 26.38 \\
\hline Accessible parking area & 3.78 & 33.99 \\
\hline Neat (clean) surroundings & 3.99 & 24.51 \\
\hline The restaurant is worth the distance travelled & 3.99 & 24.71 \\
\hline The restaurant enhances indirect distribution & 3.37 & 38.43 \\
\hline
\end{tabular}




\section{Marketing a obchod}

Tab. 2: Analysis of the assessments of quality (descriptive statistics) - Part 2

\begin{tabular}{|c|c|c|}
\hline Quality dimensions (7P) & Mean & $\begin{array}{c}\text { Coefficient } \\
\text { of variation (\%) }\end{array}$ \\
\hline \multicolumn{3}{|l|}{ Processes } \\
\hline Prompt responsiveness of staff to questions & 4.24 & 21.84 \\
\hline Helpfulness of staff in satisfying clients' needs & 4.04 & 24.80 \\
\hline Responsiveness of service staff & 4.18 & 21.10 \\
\hline Restaurant opening hours & 4.29 & 19.81 \\
\hline Waiting time & 4.10 & 22.00 \\
\hline
\end{tabular}

Source: own

Tab. 3:

Rotated factor solution

\begin{tabular}{|c|c|c|c|}
\hline \multirow[b]{2}{*}{ Quality factors (QF) } & \multirow[b]{2}{*}{ People } & \multicolumn{2}{|c|}{ Quality dimensions } \\
\hline & & Placement & $\begin{array}{c}\text { Product and Physical } \\
\text { evidences }\end{array}$ \\
\hline Helpfulness of staff in satisfying guests' needs & 0.879 & -0.096 & 0.047 \\
\hline $\begin{array}{l}\text { Immediate responsiveness of staff to guests' } \\
\text { questions }\end{array}$ & 0.751 & -0.045 & -0.049 \\
\hline Signs of special attention and compliments & 0.740 & 0.024 & 0.144 \\
\hline Responsiveness of service staff & 0.709 & -0.006 & -0.096 \\
\hline Recommendations from service staff & 0.649 & 0.094 & -0.034 \\
\hline Competences of service staff & 0.646 & 0.038 & -0.137 \\
\hline Hospitable staff & 0.551 & 0.054 & -0.158 \\
\hline Sufficient number of staff for ensuring quality service & 0.473 & 0.019 & -0.187 \\
\hline Value for money & 0.450 & 0.084 & -0.178 \\
\hline The restaurant is worth the distance travelled & 0.259 & 0.448 & -0.074 \\
\hline Accessible parking area & -0.104 & 0.759 & 0.038 \\
\hline Accessible entrance & 0.082 & 0.733 & 0.020 \\
\hline Neat (clean) surroundings & 0.094 & 0.602 & -0.104 \\
\hline Taste & 0.027 & -0.041 & -0.747 \\
\hline Appearance & 0.002 & -0.016 & -0.743 \\
\hline Food safety perception & -0.072 & 0.022 & -0.729 \\
\hline Sense of security & -0.041 & 0.097 & -0.676 \\
\hline Extent of portions & -0.026 & -0.008 & -0.667 \\
\hline Selection of dishes & 0.108 & -0.060 & -0.649 \\
\hline Comfort & 0.138 & 0.088 & -0.502 \\
\hline Cleanliness of the premises & 0.211 & 0.094 & -0.495 \\
\hline Neat (presentable) staff & 0.328 & 0.054 & -0.416 \\
\hline Design in accordance with food offer & 0.320 & 0.044 & -0.395 \\
\hline Explained variance $\%$ & 40.973 & 5.058 & 4.221 \\
\hline
\end{tabular}


could not confirm a normal distribution for any of the selected quality factors of the first set (Kolmogorov Smirnov Test (KMO) was used), it was necessary for us to use the Principal Axis Factoring method for the exploratory factor analysis. The first test was performed in order to evaluate the suitability of information for inclusion in the factor model. Thus, on the basis of the value of the KMO measure of sampling adequacy (0.958), as well as the outcome of the Bartlett test of sphericity $\left(\chi^{2}=31,071.468\right.$; degrees of freedom $=595)$, we estimated that all included variables are suitable for factor analysis. The majority of factors had satisfactory communalities $(>=0.50)$, suggesting that the greater part of their variability can be explained by the influence of common factors, the three variables with too low communalities ("presence of Manager (0.132)", "distracting presence of other guests (0.190)" and "advertising activities in the social media (0.251)" - were excluded from the evaluation process of the factor model. After a few successive iterations of the factor model evaluation, we finally selected as most appropriate the factor model with 23 factors (presented in Tab. 3); while 12 factors had to be removed from further analysis. The suitability of information for inclusion in the final factor model is also supported by the values of the KMO indicator (0.957) and the outcome of the Bartlett test $\left(\chi^{2}=223,289.398\right.$; degrees of freedom $=253$ ). Based on a rotated factor solution, we have chosen a final model with three factor groups (quality dimensions), as it allows for a more meaningful interpretation of the factor model. The final model with three quality dimensions is presented in Table 3. Factor weights with factor loadings above 0.3 and factors that contain more than three items were retained.

We started our factor analysis with seven quality dimensions, as, following Kotler's marketing theory, we have hypothesized that all seven quality dimensions have a significant influence on guests' overall quality perception. Based on the rotated matrix of factor weights shown in the table above, it is evident that guests' perception of the quality of restaurant offerings is mainly based on the quality of the following marketing factors: people (40.97\%), placement $(5.05 \%)$, product (food) and physical evidences $(4.22 \%)$. Based on these three quality dimensions (see explanation below) and the values of their total explained variances, it is clearly evident that the quality of people (staff) has the greatest importance $(40.97 \%)$ in assuring restaurant quality, followed by the quality of placement $(5.05 \%)$ and the quality of food and physical evidences (4.22\%). Other marketing quality dimensions are, in relation to guests' assessment of quality, not statistically significant. Special attention should be paid to the third factor, which is formed by merging the two dimensions of food and physical evidences. As further dissection of the results does not contribute to the improvement of the quality of the research, we have decided to keep the model with three main factors. These results clearly do not support $\mathrm{H} 1$, as only three marketing quality dimensions have a statistically significant influence on guests' quality perception. The relation between the theoretical construct and the research results is presented in Figure 1. On the left side, the 7P marketing quality dimensions are presented with initial 35 quality factors, while on the right side the research results, with the final 3 dimensions and 23 factors are presented. Twelve factors had to be removed from the factor analysis, as they had low communalities $(<0.5)$ and low factor weights $(<0.3)$. Thus, the results of this study indicate that guests perceive restaurant quality based on only three marketing quality dimensions and 23 quality factors (see also Tab. 3).

Although the findings presented above clearly indicate non-coherency of perceived quality, we have decided to further empirically investigate the differences between different quality dimensions. Based on the comparison of mean values presented in Table 2, we statistically analysed the perceived differences between all quality dimensions. Paired $t$ statistics and two-sided tests were used for all possible pairs. Statistically significant differences were found between all quality dimensions (the only exception is the comparison between the mean value of the dimensions of product and physical evidences, for which the degree of significance is 0.510 ). This indicates that the offered quality is perceived as highly incoherent; thus, $\mathrm{H} 2$ cannot be confirmed. Contrary to expectations, this study did not confirm the coherency of perceived quality in restaurants' offerings.

\section{Conclusion and Implications}

The purpose of this study was to determine how different marketing factors influence restaurant guests' overall quality perception. 


\section{Fig. 1: Theoretical model and research results}

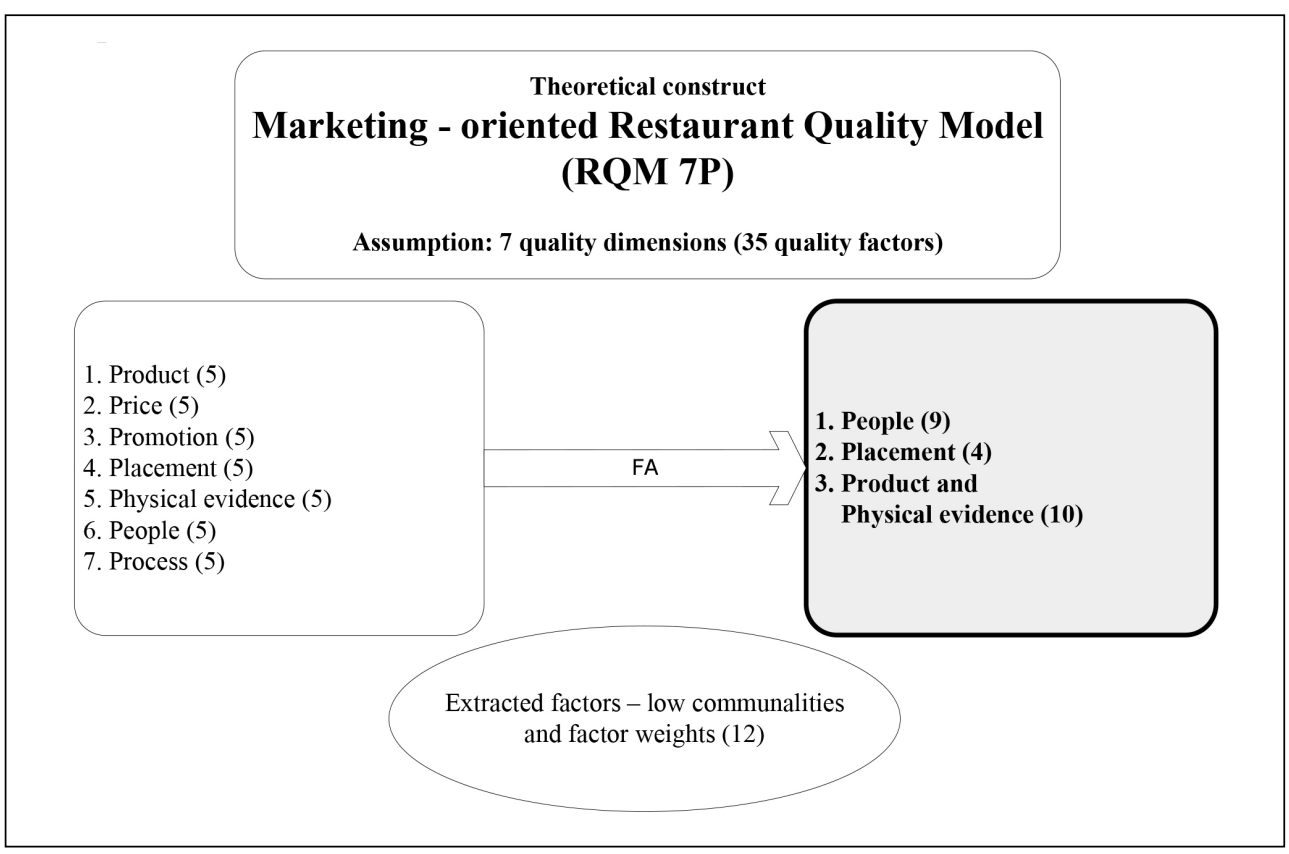

Source: own

Based on the qualitative research, we were unable to determine the significance of different marketing factors, as the results of several presented studies are mutually inconsistent and contradictory. Another important finding that emerges from the literature review is that researchers base their studies on modified research models. This finding is in accordance with our earlier observations, which have shown that service quality dimensions cannot be generalised. Thus we have developed and tested a new marketing-oriented model based on universally comprehensive marketing methodology (7P) and includes the specifics of the restaurant industry terminology. As the model is based on a solid theoretical basis (literature overview) and marketing approach (7P), we consider the findings to be generally verifiable and applicable. This study has shown that only three (out of seven) main marketing dimensions have a statistically significant influence on guests' perception of restaurant quality - (1) people, (2) placement, and (3) product (food) and physical evidences, while other marketing factors are statistically insignificant. It was also shown that guests' perceived restaurant quality as highly incoherent. Returning to the research question posed at the beginning of this study, it appears that that the quality of staff has the greatest significance in ensuring restaurant quality. The present study also confirms previous findings (Andaleeb \& Conway, 2006; Jaafar et al., 2008; Mosavi \& Ghaedi 2012; Voon, 2012) and contributes additional evidence to suggest that people are definitely the most important marketing quality dimension in the restaurant industry. Another important finding was that the quality of food has little significance in determining the perception of restaurant quality, despite the fact that the vast majority of guests reported that they visited the restaurant with the intention of satisfying hunger and thirst. Therefore, regardless of the purpose of the visit, guests evaluate the quality of restaurant offerings according to the quality of the staff. Taken together, these results suggest that not all seven marketing factors are significant in ensuring restaurant quality. 
This research extends our knowledge of restaurant management quality. The key strength of this study is its sample size. Moreover, this is the first time that all seven marketing factors have been used to explore restaurant quality. As the methodology is based on Kotler's (2004) marketing approach, we assume that it may be applied to other facilities elsewhere in the world.

A number of important limitations need to be considered. The current study only examined domestic guests' perceptions of restaurant quality in Slovenia; thus, additional caution must be applied, as the findings might not be transferable to full-board restaurant facilities that operate within hotels and other lodging facilities. Moreover, the importance of restaurant image was not included in the study. This research has generated many questions in need of further investigation. Future research should use different methodologies to replicate the findings of this study and to extend the current findings. What is now needed is a cross-national study involving different segments of guests in different types of food and beverage facilities. Large and randomised controlled trials combining both quantitative and qualitative research methods (Vila, Rovira, Costa, \& Santoma, 2012) could provide more definitive evidence of the importance of the presented results in ensuring overall restaurant quality. More research is required to determine the significance of coherency to overall restaurant quality. Concerning the importance of people, further research focusing on the role of this dimension would provide a more detailed understanding of how to treat human aspects in restaurant quality management. A further study could assess the long-term effects of different marketing quality dimensions on guests' loyalty. Future trials should also examine the predictive ability of marketing factors on the overall service quality and financial performance of the restaurant industry with the help of Structural Equation Modelling (SEM).

For restaurant managers, the results indicate the value of investing substantial effort in understanding the complexity of human interactions. The essence of recruiting strategies, formal education and informal trainings must be recognised and encouraged. People (service staff) play a major role in guests' perception of overall restaurant quality. Their significance in ensuring overall restaurant quality is much more complex than simply seating guests, taking orders and serving the customers. Restaurant managers must therefore rethink the role their employees play in ensuring overall restaurant quality. Furthermore, as people (staff) present only one dimension of the restaurant marketing mix, managers must constantly measure the quality of their offering and adjust their marketing plans and strategies in order to ensure guests' satisfaction and the overall quality of the offering.

\section{References}

Abdullah, A. D., \& Rozario, F. (2009). Influence of service and product quality towards customer satisfaction: A case study at the staff cafeteria in hotel industry. World Academy of Science, Engineering and Technology, 3(5), 35-40.

Aigbedo, H., \& Parameswaran, R. (2004). Importance-performance analysis for improving Quality of campus food service. International Journal of Quality in Reliability Management, 21(8), 876-896. doi:10.1108/02656710410551755.

Andaleeb, S. S., \& Conway, C. (2006). Customer satisfaction in the restaurant industry: an Examination of the transaction-specific model. Journal of Services Marketing, 20(1), 3-11. doi:10.1108/08876040610646536.

Ayeh, J. K., \& Chen, R. X. (2013). How's the Service? A Study of Service Quality Perceptions across Sectors and Source Markets. International Journal of Tourism Research, 15(3), 241-260. doi:10.1002/jtr.1864.

Barber, N., Goodman, R. J., \& Goh, B. K. (2011). Restaurant consumers repeat patronage: A Service quality concern. International Journal of Hospitality Management, 30(2), 329-336. doi:10.1016/j.ijhm.2010.08.008.

Barber, N., \& Scarcelli, J. M. (2010). Enhancing the assessment of tangible service quality through the creation of a cleanliness measurement scale. Managing Service Quality, 20(1), 70-88. doi:10.1108/09604521011011630.

Bhattachnaya, A., \& Friedman, H. H. (2001). Using Smart Pricing to Increase Profits and Maximize Customer Satisfaction. Retreived May 9, 2014, from http://www.connection. ebscohost.com\&c\& articles\&5482557\&usingsmart-pricing-Increase-profits-maximizecustomer-satisfaction.

Bowie, D., \& Buttle, F. (2004). Hospitality Marketing: an introduction. Oxford: Elsevier Butterworth-Heinemann. 
Candido, C. J. F., \& Morris, D. S. (2000). Charting service quality gaps. Total Quality Management, 11(4), 463-472. doi:10.1080/09544120050007779.

Cousins, J., Foskett, D., \& Gillespie, C. (2002). Food and beverage management. Harlow: Prentice Hall.

Cronin, J. J., \& Taylor, S. A. (1994). SERVPERF versus SERVQUAL: Reconciling Performance-Based and Perceptions-MinusExpectations Measurement of Service Quality. Journal of Marketing, 58(1), 125-131. doi:10.2307/1252256.

Dedeke, A. (2003). Service quality: a fulfilment-oriented and interactions-centred approach. Managing Service Quality, 13(4), 276-289. doi:10.1108/09604520310484699.

Din, N., Zahari, M. S. M., Othman, C. N., \& Abas, R. (2012). Restaurant Operator's Receptiveness towards Providing Nutritional Information on Menu. Procedia - Social and Behavioral Sciences, 50, 699-709. doi:10.1016/j.sbspro.2012.08.073.

Edvardsson, B. (2005). Service quality: beyond cognitive assessment. Managing Service Quality, 15(2), 127-131. doi:10.2307/1252296.

Edwards, J. S. (2013). The foodservice industry: Eating out is more than just a meal. Food Quality and Preference, 27(2), 223-229. doi:10.1016/j.foodqual.2012.02.003.

Grönroos, C. (1984). A Service Quality Model and its Marketing Implications. European Journal of Marketing, 18(4), 36-44. doi:10.1108/ EUM0000000004784.

Grönroos, C. (1990). Relationship approach to marketing in service contexts: The marketing and organizational behaviour interface. Journal of Business Research, 20(1), 3-11. doi:10.1016/0148-2963(90)90037-E.

Gupta, S., McLaughlin, E., \& Gomez, M. (2007). Guest Satisfaction and Restaurant Performance. Cornell Hotel and Restaurant Administration Quarterly, 48(3), 284-298. doi:10.1177/0010880407301735.

Ha, J., \& Jang, S. (2010). Effects of service quality and food quality: The Moderating role of Atmospherics in an ethnic restaurant segment. International Journal of Hospitality Management, 29(3), 520-529. doi:10.1016/j. ijhm.2009.12.005.

Han, H., Back, K. J., \& Barrett, B. (2010). A consumption emotion measurement development: a full-service restaurant setting.
The Service Industries Journal, 30(2), 299-320. doi:10.1080/02642060802123400.

Heung, V. C. S., Wong, M. Y., \& Qu, H. L. (2000). Airport-restaurant service quality in Hong Kong: an application of SERVQUAL. Cornell Hotel and Restaurant Administration Quarterly, 41(3), 86-96. doi:10.1016/S00108804(00)80020-8.

Jaafar, S. N., Lumbers, M., \& Eves, A. (2008). Eating out: what really matters? Hospitality Review, 10(3), 47-54.

Jensen, Ø., \& Hansen, K. V. (2007). Consumer values among restaurant customers. International Journal of Hospitality Management, 26(3), 603-622. doi:10.1016/j. ijhm.2006.05.004.

Juwaheer, T. D. (2004). Exploring international tourists' perceptions of hotel operations by using a modified SERVQUAL approach - a case study of Mauritius. Managing Service Quality, 14(5), 350-364. doi:10.1108/09604520410557967.

Keith, N. K., \& Simmers, C. S. (2011). Measuring Service Quality Perceptions of Restaurant Experiences: The Disparity between Comment Cards and DINESERV. Journal of Foodservice Business Research, 14(1), 20-32. doi:10.1080/15378020.2011.548209.

Keller, E. (2007). Unleashing the power of word of mouth creating brand advocacy to drive growth. Journal of advertising research, 47(4), 448-452. doi:10.2501/S0021849907070468.

Kim, H. M., \& Kachersky, L. (2006). Dimensions of price salience: a conceptual framework for perceptions of multidimensional prices. Journal of Product in Brand Management, 15(2), 139-147. doi:10.1108/10610420610658974.

Kim, W. G., \& Moon, Y. J. (2009). Customers' cognitive, emotional, and actionable response to the servicescape: A test of the moderating effect of the restaurant type. International Journal of Hospitality Management, 28(1), 144-156. doi:10.1016/j.ijhm.2008.03.005.

Kim, W. G., Ng, C. Y. N., \& Kim, Y. (2009). Influence of institutional DINESERV on Customer satisfaction, return intention, and word-of-mouth. International Journal of Hospitality Management, 28(1), 10-17. doi:10.1016/j.ijhm.2008.03.005.

Kotler, P. (2004). Management trženja. Ljubljana: GV založba.

Landrum, H., Prybutok, V. R., \& Zhang, X. (2007). A comparison of Magal's service quality 
instrument with SERVPERF. Information and Management, 44(1), 104-113. doi:10.1016/j. im.2006.11.002.

Langer, M. (1997). Service Quality in Tourism: measurement methods and empirical analysis. Frankfurt am Main: Peter Lang.

Lehtinen, U., \& Lehtinen, J. R. (1991). Two Approaches to Service Quality Dimensions. The Service Industries Journal, 11(3), 287-303. doi:10.1080/02642069100000047.

Lin, S. P., Chan, Y. H., \& Tsai, M. C. (2009). A transformation function corresponding to IPA and gap analysis. Total Quality Management in Business Excellence, 20(8), 829-846. doi:10.1080/14783360903128272.

Llosa, S., Chandon, J. L., \& Orsingher, C. (1998). An Empirical Study of Servqual's Dimensionality. The Service Industries Journal, 18(2), 16-44. doi:10.1080/02642069800000017.

Luohe, H. F., \& Tsaur, S. H. (2011). Customers' perceptions of service quality: Do servers' Age stereotypes matter? International Journal of Hospitality Management, 30(2), 283-289. doi:10.1016/j.ijhm.2010.09.002.

Marković, S., Raspor, S., \& Šegarić, K. (2012). Does Restaurant Performance Meet Customers' Expectations? An Assessment of Restaurant Service Quality Using a Modified Dineserv Approach. Retrieved May 1, 2014, from http://hrcak.srce.hr/file/93311.

Martínez-Tur, V., Tordera, N., Peiró, J. M., \& Potocnik, K. (2011). Linking Service Climate and Disconfirmation of Expectations as Predictors of Customer Satisfaction: A Cross-Level Study. Journal of Applied Social Psychology, 41(5), 1189-1213. doi:10.1111/ j.1559-1816.2011.00753.x.

Mattila, A. S., \& Wirtz, J. (2001). Congruency of scent and music as a driver of in-store evaluations and behaviour. Journal of Retailing, 77(2), 273-289. doi:10.1016/S00224359(01)00042-2.

Meng, J. G., \& Elliott, K. M. (2008). Predictors of relationship quality for luxury Restaurants. Journal of Retailing and Consumer Services, 15(6), 509-515. doi:10.1016/j. jretconser.2008.02.002.

Mosavi, S. A., \& Ghaedi, M. (2012). The effects of relationship marketing on Relationship quality in luxury restaurants. African Journal of Business Management, 6(19), 6090-6102. doi:10.5897/ajbm11.2192.

Nam, J., Ekinci, Y., \& Whyatt, G. (2011). Brand equity, brand loyalty and consumer satisfaction. Annals of Tourism Research, 38(3), 1009-1030. doi:10.1016/j.annals.2011.01.015.

Parasuraman, A., Zeithaml, V. A., \& Berry, L. L. (1985). A Conceptual Model of Service Quality and Its Implications for Future Research. Journal of Marketing, 49(4), 41-50. doi:10.1016/S0022-4359(05)80007-7.

Parasuraman, A., Zeithaml, V. A., \& Berry, L. L. (1988). Servqual: A multiple item Scale for measuring consumer perceptions of service quality. Journal of Retailing, 64(1), 12-40.

Parasuraman, A., Berry, L. L., \& Zeithaml, V. A. (1993). More on improving service quality measurement. Journal of Retailing, 69(1), 140-147. doi:10.1016/S0022-4359(05)80007-7.

Parasuraman, A., Zeithaml, V. A., \& Berry, L. L. (1994). Reassessment of Expectations as a Comparison Standard in Measuring Service Quality. Implications for Further Research. Journal of Marketing, 58(1), 111-124.

Parsa, H. G., Self, J., Sydnor-Busso, S., \& Yoon, H. J. (2011). Why Restaurants Fail? Part II - The Impact of Affiliation, Location, and Size on Restaurant Failures: Results from a Survival Analysis. Journal of Foodservice Business Research, 14(4), 360-379. doi:10.10 80/15378020.2011.625824.

Raajpoot, N. A. (2002). Tangserv. Journal of Foodservice Business Research, 5(2), 109-127. doi:10.1300/J369v05n02_08.

Reeves, C. A., \& Bednar, D. A. (1995). Quality as Symphony. Cornell Hotel and Restaurant Administration Quarterly, 36(3), 72-79. doi:10.1177/001088049503600323.

Rood, S., \& Dziadkowiec, J. (2011). Applying the Dineserv and IPA methods to a cross Cultural comparison of quality service gaps. Retrieved May 17, 2014, from http:// heami.org\&uploads\&RoodDziadkowiec_ Applying_the_DINESERV_and_IPA_Methods_ to_Cross_Cultural_Service_Gaps.pdf.

Ryu, K. (2005). DINESCAPE, emotions, and behavioural intentions in upscale restaurants. RetrievedFebruary7,2014, fromhttp://webcache. googleusercontent.com/search?q=cache:-09 Z7g3dc4J:www.researchgate.net/publication/ 29867433 _DINESCAPE_emotions and_behavioral_intentions_in_upscale_ restaurants/file/e0b4952 d 4 d8f56d8ff. $p d f+\& c d=1 \& h l=s \mid \& c t=c l n k \& g l=s i$.

Ryu, K., \& Jang, S. S. (2007). The Effect of Environmental Perceptions on Behavioral Intentions through Emotions: The Case of Upscale Restaurants. Journal of 
Hospitality in Tourism Research, 31(1), 56-72. doi:10.1177/1096348006295506.

Sedmak, G. (2011). Menedžment prehrambenih obratov. Koper: UP Annales.

Sharma, S., Wagle, A., Sucher, K., \& Bugwadia, N. (2011). Impact of Point of Selection Nutrition Information on Meal Choices at a Table-Service Restaurant. Journal of Foodservice Business Research, 14(2), 146-161. doi:10.1080/15378020.2011.574540.

Sulek, J. M., \& Hensley, R. L. (2004). The Relative Importance of Food, Atmosphere, and Fairness of Wait the Case of a Full-service Restaurant. Cornell Hotel and Restaurant Administration Quarterly, 45(3), 235-247. doi:10.1177/0010880404265345.

Taylor, G. A., \& Long-Tolbert, S. (2002). Coupon Promotions in Quick-service Restaurants: Preaching to the Converted? Cornell Hotel and Restaurant Administration Quarterly, 43(41), 41-47. doi:10.1016/S0010-8804(02)80040-4.

Van Vaerenbergh, Y., Larivière, B. \& Vermeir, I. (2012). The impact of process recovery communication on customer satisfaction, repurchase intentions, and word-of-mouth intentions. Journal of Service Research, 15(3), 262-279. doi:10.1177/1094670512442786.

Vanniarajan, T. (2009). DINESERV: A tool for measuring service quality in restaurants. Journal of Marketing and Communication, 4(3), 41-52. doi:10.1016/0010-8804(95)93844-K.

Vila, M., Rovira, X., Costa, G., \& Santoma, R. (2012). Combining research techniques to improve quality service in hospitality. Quality and Quantity, 46(3), 795-812. doi:10.1007/ s11135-010-9414-9.

Voon, B. H. (2012). Role of Service Environment for Restaurants: The Youth Customers' Perspective. Procedia - Social and Behavioral Sciences, 38, 388-395. doi:10.1016/j.sbspro.2012.03.361.
Wall, E. A., \& Berry, L. L. (2007). The Combined Effects of the Physical Environment and Employee behavior on Customer Perception of Restaurant Service Quality. Cornell Hotel and Restaurant Administration Quarterly, 48(1), 59-69. doi:10.1177/0010880406297246.

Wang, L., Law, R., Hung, K., \& Guillet, B. D. (2014). Consumertrustin tourismand Hospitality: A review of the literature. Journal of Hospitality and Tourism Management, 21(December), 1-9. doi:10.1016/j.jhtm.2014.01.001.

Waxman, L. (2006). The Coffee Shop: Social and Physical factors Influencing Place Attachment. Journal of Interior Design, 31(3), 35-53. doi:10.1111/j.1939-1668.2006. tb00530.x.

Yunkyong, K. (2007). A study of understanding the impact of physical environment on perceived service quality in the hotel industry. Retrieved October 9, 2013, from http://digital.library.okstate.edu/etd/umiokstate-2208.pdf.

Zeithaml, V. A., Berry, L. L., \& Parasuraman, A. (1988). Communication and Control Processes in the Delivery of Service Quality. Journal of Marketing, 52(2), 35-48. doi:10.2307/1251263.

Marko Kukanja, M. sc., senior lecturer University of Primorska Faculty of Tourism Studies - Turistica Marko.Kukanja@fts.upr.si

Doris Gomezelj Omerzel, Ph.D., Assoc. Prof. University of Primorska Faculty of Management Doris.Gomezelj@fm-kp.si

Boris Bukovec, Ph.D., Assoc. Prof. Faculty of Organisation Studies in Novo Mesto Boris.Bukovec@fos.unm.si 


\title{
Abstract
}

\section{A RESTAURANT QUALITY MODEL BASED ON MARKETING FACTORS}

\author{
Marko Kukanja, Doris Gomezelj Omerzel, Boris Bukovec
}

Previous studies have highlighted the importance of several quality factors in guests' assessment of restaurant quality. As there is no general consensus on which marketing quality factors really matter in assessing the quality of the dining experience in the previous literature, this paper describes and tests the development of a marketing-oriented Restaurant Quality Model (RQM $7 P)$. In addition, this study tests whether guests' perceive overall restaurant quality offerings as coherent. Special attention was devoted to a marketing perspective (7P). Following the discussion of the conceptualization and operationalization of the restaurant quality construct, the procedures used in constructing and refining a multiple-item scale to measure restaurant quality are described. Evidence of the scale's reliability, factor structure and validity on the basis of analysing data is presented next. A sample of 1,998 valid questionnaires obtained by domestic guests in different restaurant facilities in Slovenia is analysed. Results show that guests perceive restaurant quality according to three marketing quality dimensions - (1) people, (2) placement, and (3) product (food) and physical evidences, while other marketing factors are not statistically significant in determining restaurant quality. In addition, the results indicate that guests perceive restaurant quality offerings as highly incoherent. From a theoretical point of view, this study contributes by developing a restaurant quality model based on marketing factors. In addition, it is the first study to test the perception of all seven marketing dimensions in the restaurant industry, and it provides insights regarding how guests perceive restaurant offering coherency. This research has thrown up many questions in need of further investigation. Future research should include a cross-national study involving different segments of guests in different types of food and beverage facilities.

Key Words: Restaurant quality, service quality management, F\&B management, marketing mix, Slovenia.

JEL Classification: L83, L15.

DOI: 10.15240/tul/001/2017-1-011 